\title{
NÁVRH EFEKTIVNÍHO SYSTÉMU POŠTOVNÍ OBSLUHY NA ÚZEMÍ TĚŠÍNSKA A TŘINECKA
}

\author{
Barbora Chromcová ${ }^{1}$, Libor Švadlenka ${ }^{2}$
}

\section{Úvod}

Česká pošta s. p. (dále jen ČP), jakožto národní poštovní operátor České republiky (dále jen ČR), se v současné době intenzivně připravuje na okamžik plného otevření poštovního trhu ČR, které je naplánováno na 1. 1. 2013. Prováděná restrukturalizace podniku zasahuje jak do obchodní, tak také do logistické činnosti podniku.

Cílový stav logistiky ČP je definován jako systémová přestavba poštovní sítě, k čemuž má být využito nejmodernějších technologií a moderních optimalizačních metod.

Centralizace, jejímž výsledkem je nový a efektivní systém obsluhy území, je ve své podstatě nástrojem pro optimalizace dodací služby, jež se týká především balíkového segmentu. Pro samotnou centralizaci jsou obecně definovány následující kroky:

- analýza poštovní sítě a atrakčního obvodu,

- umístění depa do sítě,

- určení optimálního počtu atrakčních obvodů,

- návrh tras vytvořených atrakčních obvodů,

- výpočet zátěže nových atrakčních obvodů,

- zajištění svozu a rozvozu poštovního materiálu.

Pro názornou ukázku, jak je možné postupovat v př́padě vytvoření návrhu na efektivní systém obsluhy, bylo vybráno území na Severovýchodě Moravy, které je jedno z neproblémovějších, vzhledem ke své rozloze a umístění. Oblast, v níž je zkoumán stav dodací služby, spadá pod region Severní Morava. Je zde celkem 30 pošt, z toho 5 řídících, 20 satelitních a 5 samostatných.

\footnotetext{
1 Ing. Barbora Chromcová, Univerzita Pardubice, Dopravní fakulta Jana Pernera, Katedra managementu, marketingu a logistiky, Studentská 95, 53210 Pardubice, Česká republika, tel.: +420 466036 382, E-mail: barbora.chromcova@student.upce.cz

2 Doc. Ing. Libor Švadlenka, Ph.D., Univerzita Pardubice, Dopravní fakulta Jana Pernera, Katedra dopravního managementu, marketingu a logistiky, Studentská 95, 53210 Pardubice, Tel.: 466036375, E-mail: Libor.Svadlenka@upce.cz
} 


\section{Analýza poštovní sítě}

Základním problémem analýzy poštovní sítě je neefektivní způsob přepravní a dodací služby, kdy při stávajících objemech a struktuře poštovních zásilek je neekonomické dodávat zásilky zákazníkům prŕmo ze sběrného přepravního uzlu (dále jen SPU). Další problémy působí vysoký počet automatizovaných balíkových dodejen (dále jen ABD) a samotná vytíženost těchto pracovišt'. Více než polovina těchto pracovišst' jsou tzv. malá pracoviště, která zpracovávají velmi malý počet poštovních zásilek. Dále jsou zde prostorové problémy, tj. nedostatečné manipulační plochy, nevhodné př́íjezdové komunikace a objekty budov, které dřive sloužily jiným účelům. Značná část těchto pracovišst' se nachází v centru města, nedostanou se tedy $\mathrm{k}$ nim velkoobjemová vozidla, mají nedostatečná výměniště, nevhodné rampy, vjezdy do dvora apod. To pak vyžaduje, aby ČP měla ve svém vozovém parku vozidla menšího objemu, která jsou pak v přepočtu na jednu zásilku ekonomicky méně výhodná.

Poštovní přepravní sít' je rozdělena na tři sítě, a to na hlavní, oblastní a účelovou přepravní sít'. Hlavní přepravní sít' propojuje jednotlivá SPU celé České republiky. Oblastní přepravní sít' vytváří spojení mezi SPU a poštami s pracovištěm ABD. Konkrétně se jedná o Český Těšín 1, Bystř̌ice nad Olší, Třinec 1, Hnojník a Jablunkov. Každá pošta musí být poštovním kurzem obsloužena minimálně dvakrát denně, ovšem skutečný počet zapojení je mnohonásobně vyšší. Vybrané území obsluhuje celkem 13 poštovních kurzi̊, které denně projedou až 1766 kilometrů. Do účelové přepravní sítě je zapojeno 25 pošt. Poštovní zásilky jsou sváženy do ABD místní účelovou sítí a poté kurzy oblastní přepravní sítě do SPU Ostrava. Obsluha území je zajištěna 44 atrakčními obvody a poštovní doručovatelé v této síti projedou denně až 2289 kilometrů.

\section{Analýza atrakčního obvodu}

Atrakční obvod je obvodem, který lze definovat jako množinu vrcholů, které jsou z daného depa obsluhovány. Podstatou návrhu je nahrazení pevného atrakčního obvodu doručovatele novým dynamickým atrakčním obvodem představujícím podmnožinu odevzdacích míst, který umožňuje doručení předpokládaného počtu balíkových zásilek jedním vozidlem, $\mathrm{v}$ rámci jednodenní pracovní směny doručovatele.

Na počet atrakčních obvodů má vliv několik aspektů, např.:

- prrejezdy mezi obcemi v rámci jednoho atrakčního obvodu:

snahou je snižovat čas, který doručovatel stráví pouze na přejezdech mezi jednotlivými odevzdacími místy,

- počet odevzdacích míst:

doručování se v analyzované oblasti potýká s vysokými náklady, které vznikají především díky vysokému podílu doručovací pochůzky na samotném doručovacím procesu. Některé stávající doručovací okrsky se vyznačují velkými vzdálenostmi mezi jednotlivými odevzdacími místy,

- kapacita poštovních vozů:

důležitá je otázka, kolik poštovních zásilek lze naložit do jednoho poštovního vozu. Vozový park ČP je velice různorodý a návrh předpokládá převedení poštovních vozů od řídících pošt $\mathrm{k}$ depu a obnova a unifikace tohoto vozového parku,

- rozvržení pracovní směny doručovatele: 
předpokládaná pracovní doba doručovatele je 7,5 hodin, tzn. doručovatel má jednu hodinu na př́ipravu na doručování a další jednu hodinu na všechny přejezdy. Potřebná doba pro doručování je tedy pět hodin.

\section{Umístění depa do sítě}

Řešení rozmístění poštovních provozoven je zařazováno do skupin tzv. lokačněalokačních úloh. Prvním a nejdůležitějším krokem tohoto návrhu je umístění tzv. depa do analyzované oblasti. Toto depo se stane výchozím bodem pro dodací službu a nahradí stávající ABD ve svém okolí. Poštovní kurzy, které obsluhovaly pracoviště s ABD ve zvolené oblasti, budou zrušeny. Dojde tak k př́mému spojení mezi SPU Ostrava a depem. Tímto krokem dojde k odstranění duplicitních jízd, které jsou nevyhovující vzhledem k vzrůstajícím nákladům.

Koptimálnímu umístění depa do dané lokality lze využít teorii grafů. Pomocí Floydova algoritmu je možné nalézt takové místo na grafu, kdy dojezdy z přidělených míst budou co nejmenší. Podkladem pro výpočet algoritmu je graf na Obrázku č. 1, který zjednodušeně znázorňuje silniční sít', tedy všechna možná spojení mezi řídícími poštami, včetně jejich vzdáleností v kilometrech.

Obrázek č. 1 - Silniční sít' mezi řídícími poštami

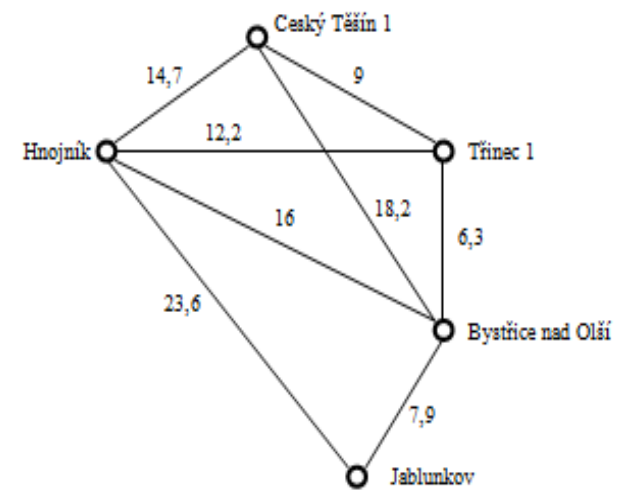

Výše znázorněný graf (obrázek č. 1) je podkladem pro maticí vzdáleností, která je výchozí maticí pro Floydův algoritmus. Pro jednodušší označení vrcholů matice budou názvy měst nahrazeny pořadovým číslem, tzn.: Český Těšín bude vrcholem $v_{1}$, Hnojník $v_{2}$, Třinec $\mathrm{v}_{3}$, Bystřice nad Olší $\mathrm{v}_{4}$ a poslední Jablunkov jako $\mathrm{v}_{5}$. Výchozí matice pro Floydův algoritmus je následující, viz tabulka č. 1 .

Tabulka č. 1 - Výchozí matice pro Floydi̊v algoritmus

\begin{tabular}{|c|c|c|c|c|c|}
\hline & $\mathrm{v}_{1}$ & $\mathrm{v}_{2}$ & $\mathrm{v}_{3}$ & $\mathrm{v}_{4}$ & $\mathrm{v}_{5}$ \\
\hline $\mathrm{v}_{1}$ & 0 & 14,7 & 9 & 18,2 & $\infty$ \\
\hline $\mathrm{v}_{2}$ & 14,7 & 0 & 12,2 & 16 & 23,6 \\
\hline $\mathrm{v}_{3}$ & 9 & 12,2 & 0 & 6,3 & $\infty$ \\
\hline $\mathrm{v}_{4}$ & 18,2 & 16 & 6,3 & 0 & 7,9 \\
\hline $\mathrm{v}_{5}$ & $\infty$ & 23,6 & $\infty$ & 7,9 & 0 \\
\hline
\end{tabular}


Smyslem Floydova algoritmu je přepočítávání prvků v matici podle následujícího pravidla: $\mathrm{c}_{\mathrm{ij}}=\min \left\{\mathrm{c}_{\mathrm{ij}}, \mathrm{c}_{\mathrm{ik}}+\mathrm{c}_{\mathrm{kj}}\right\}$. Přepočet se provádí do té doby, než se proměnná $\mathrm{k}=5$. Z výsledku Floydova algoritmu je zřejmé, že jako výchozí bod dodací služby se jeví vrchol $\mathrm{v}_{3}$, tedy město Třinec. Toto depo bude do poštovní sítě zapojeno př́mým způsobem, tedy stálou trasou mezi Ostravou a Třincem. Délka trasy pro jeden kurz je 44,3 kilometrů.

\section{Určení optimálního počtu atrakčních obvodů}

Pro stanovení optimálního počtu atrakčních obvodů je vybrána manažerská metoda rozhodování, která je optimalizační a bere do úvahy všechny kritéria, které mají vliv na jednotlivé varianty. Východiskem pro stanovení možných variant je poměr mezi plánovaným objemem zásilek ke zpracování v př́islušném depu, konkrétně 1450 zásilek, a maximálním možným počtem zásilek, kterým lze zatížit balíkového doručovatele, jedná se o 125, 100, 90 a 80 poštovních zásilek. Výsledkem jsou následující varianty (12, 15, 17 a 19 atrakčních obvodů), z nichž bude vybrána ta optimální.

Proto, aby byl správně určen počet atrakčních obvodů, je důležité stanovit kritéria, včetně jejich vah. Jako kritéria byly stanoveny: projezdové kilometry, zátěž atrakčního obvodu a náklady na balíkového doručovatele. Pro potřeby stanovení vah těchto kritérií byla vybrána Saatyho metoda, která určuje velikost preference jednotlivých kritérií, jež se vyjadřují počtem bodů $\mathrm{z}$ určené bodové stupnice. Preferenční vztah je určen na základě pokladů získaných z expertního odhadu.

Dalším krokem je aplikování metody lineární dílčí funkce utility, která poslouží pro stanovení reálného počtu atrakčních obvodů. Postup je následující: pomocí metody jsou vypočtena dílčí ohodnocení, ta jsou pak vynásobená př́íslušnou váhou, a tím se získají hodnoty, ze kterých se vybere maximální hodnota, která určuje optimální variantu, což podle metody vícekriteriálního rozhodování je 17 atrakčních obvodů.

\section{Návrh tras vytvořených atrakčních obvodů}

Je-li znám počet atrakčních obvodů, je dalším krokem návrhu trasování těchto obvodů. Poštovní doručovatel má povinnost při pochůzce navštívit každé místo (obec nebo město) pouze jednou a vrátit se do depa odkud vyšel s tím, že jeho celková projetá vzdálenost bude minimální. Pro výpočet trasy je vhodné použít Littlův algoritmus. Je důležité ještě zmínit, že rozdělení měst a obcí do př́slušných atrakčních obvodů je prováděno empirickou metodou, a to pozorováním.

Výchozím podkladem pro Littlův algoritmus je matice vzdáleností. Při uplatňování postupu Littlova algoritmu dochází k redukci výchozí matice. Na konci výpočtu zůstane matice o velikosti pouze $1 \times 1$. Výsledkem celého výpočtu je vytvoření směru doručovací pochůzky, která se vyznačuje minimálními projezdovými kilometry. Vytvořené atrakční obvody, včetně jejich vzdáleností, je možno vidět na Obrázku č. 2. 
Obrázek č. 2 - Projezdové kilometry atrakčních obvodů

\begin{tabular}{|c|c|c|c|c|c|c|c|c|c|c|c|c|c|c|c|c|c|}
\hline & obce a města & $\mathrm{km}$ & & obce a města & $\mathrm{km}$ & & obce a města & $\mathrm{km}$ & & obce a města & $\mathrm{km}$ & & obce a města & $\mathrm{km}$ & & obce a města & $\mathrm{km}$ \\
\hline 1. & $\begin{array}{l}\text { Horní } \\
\text { Lomná, } \\
\text { Dolní Lomná }\end{array}$ & 50 & 4. & $\begin{array}{l}\text { Třrinec 1, } \\
\text { Třrinec 3, } \\
\text { Kojkovice }\end{array}$ & 15 & 7. & $\begin{array}{l}\text { Chotěbuz, } \\
\text { Stanislavice }\end{array}$ & 38 & 10. & $\begin{array}{l}\text { Nýdek, } \\
\text { Bystřice }\end{array}$ & 23 & 13. & $\begin{array}{l}\text { Písečná, } \\
\text { Bukovec, } \\
\text { Písek }\end{array}$ & 39 & 16. & $\begin{array}{l}\text { Smilovice, } \\
\text { Střítěž, } \\
\text { Vělopolí }\end{array}$ & 24 \\
\hline 2. & $\begin{array}{l}\text { Mosty u } \\
\text { Jablunkova, } \\
\text { Hrčava }\end{array}$ & 48 & 5. & $\begin{array}{l}\text { Třinec } 4, \\
\text { Třinec } 5, \\
\text { Třinec } 8, \\
\text { Třinec } 11\end{array}$ & 18 & 8. & $\begin{array}{l}\text { Horní } \\
\text { Tošanovice, } \\
\text { Dolní } \\
\text { Tošanovice, }\end{array}$ & 28 & 11. & $\begin{array}{l}\text { Milíkov, } \\
\text { Bocanovice }\end{array}$ & 36 & 14. & $\begin{array}{l}\text { Horní } \\
\text { Žukov, } \\
\text { Dolní } \\
\text { Žukov, }\end{array}$ & 28 & 17. & $\begin{array}{l}\text { Komorní } \\
\text { Lhotka, } \\
\text { Hnojník }\end{array}$ & 22 \\
\hline 3. & $\begin{array}{l}\text { Třinec 9, } \\
\text { Horní Líštná, } \\
\text { Vendryně }\end{array}$ & 19 & 6. & $\begin{array}{l}\text { Český Těšín } \\
1, \text { Český } \\
\text { Těšín } 3\end{array}$ & 30 & 9. & $\begin{array}{l}\text { Jablunkov, } \\
\text { Návsí, } \\
\text { Hrádek }\end{array}$ & 36 & 12. & $\begin{array}{l}\text { Tyra, Guty, } \\
\text { Řeka }\end{array}$ & 32 & 15. & $\begin{array}{l}\text { Český Těšín } \\
6, \\
\text { Mistřovice, } \\
\text { Koňakov }\end{array}$ & 24 & & & \\
\hline
\end{tabular}

\section{Zátěž nových atrakčních obvodů}

Nejdůležitější z celého návrhu je výpočet zátěže, která je závislá na výši pracovního úvazku a směnového času, a také na tzv. normominutách. Jednotlivé atrakční obvody by měly mít srovnatelnou zátěž, ovšem pouze za předpokladu, že obvody budou mezi sebou srovnatelné. To ve skutečnosti neplatí, každý atrakční obvod je jiný. Zátěž 17 atrakčních obvodů je graficky znázorněna na obrázku č. 3 .

Obrázek č. 3 - Reálná zátěž atrakčních obvodi̊

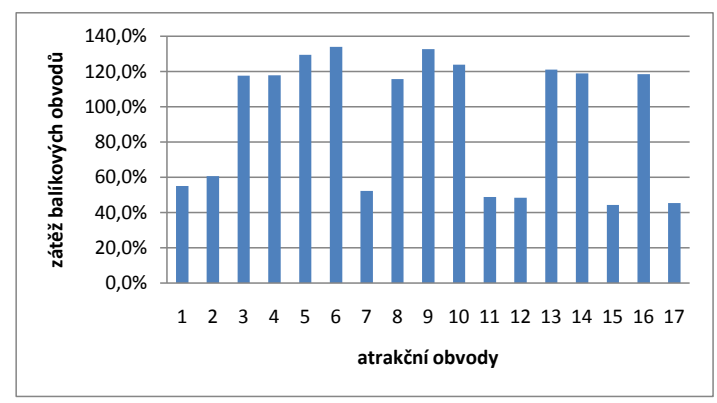

Z výše vloženého obrázku lze vyčíst jak nadprůměrnou, tak i podprůměrnou zátěž. U podprůměrných obvodů lze pro zvýšení zátěže takovýchto atrakčních obvodů využít tzv. motorizovaného doručování, tj. kombinace listovního a balíkového doručování. Po dopočítání listovní zátěže bude graf vypadat následovně, viz obrázek č. 4. 
Obrázek č. 4 - Zátěž motorizovaných atrakčních obvodi̊

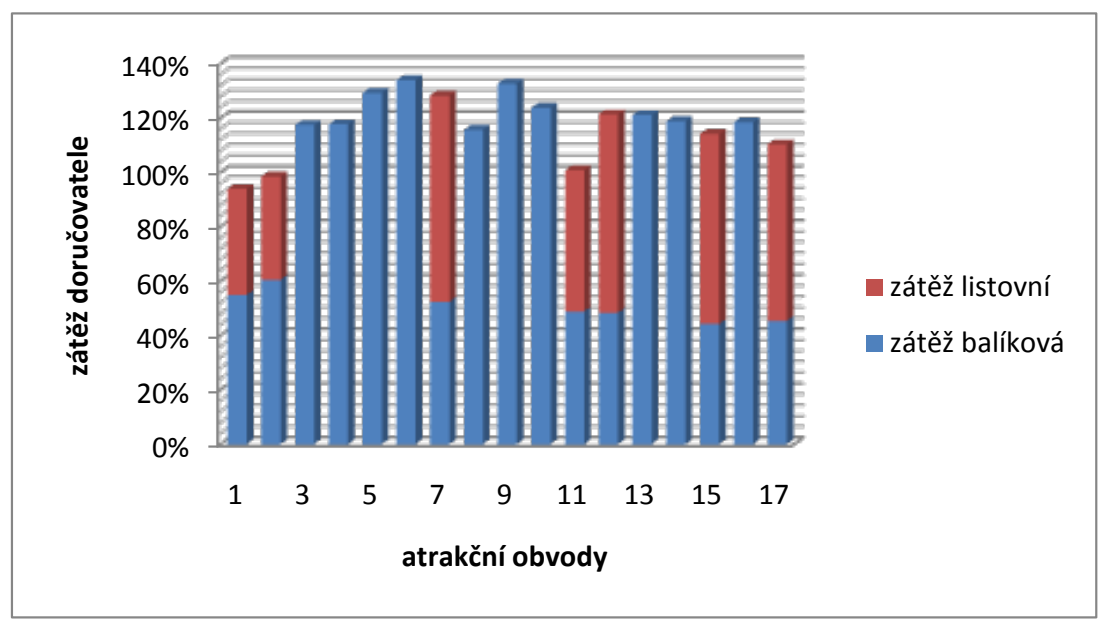

Z grafu lze nyní vyčíst nadprůměrnou zátěž téměř u všech atrakčních obvodů. Na první pohled by se mohlo zdát, že výsledný návrh je nereálný a poštovní doručovatel jej není schopen realizovat. Nicméně je nutné si uvědomit, jak je nastavena zátěž v podmínkách ČP. Zde totiž platí, že atrakční obvod je plně vytížen, pohybuje-li se zátěž na úrovni $110-130 \%$ (je vhodné zvážit, zda není na místě provést změnu norem pro doručování, aby se stala více realistickou). Pokud by i po eventuálním přepracování norem byla zátěž nadprůměrná, existuje několik možností, jak zátěž snížit. Jednou z možností jak snížit nadprůměrnou zátěž u motorizovaných atrakčních obvodů je, že činnost mohou vykonávat dva poštovní doručovatelé. Jejich atrakční obvod bude flexibilní, budou tedy vytěžováni zásilkami i jiných atrakčních obvodů, nebo mohou obsluhovat firmy, které přijímají vysoký počet zásilek. Další možností, jak snížit nadprůměrnou zátěž atrakčních obvodů je využití činností tzv. „fiktivních služebních atrakčních obvodů“, o nichž bude zmíněno v dalším kroku návrhu.

\section{Svoz a rozvoz poštovního materiálu}

V důsledku koncentrace všech poštovních kurzů k depu zaniká ranní, odpolední, večerní a sobotní obsluha pošt v oblastní přepravní síti. Poštovní kurzy v oblastní přepravní síti zásobovaly pošty peněžní hotovostí, ceninami a především poštovními zásilkami, balíkovými i listovními. V rámci účelové poštovní sítě byla peněžní hotovost a ceniny dále rozváženy satelitním a samostatným poštám. Je tedy nutné v tomto návrhu na tento fakt nezapomenout a rozvrhnout svozy a rozvozy poštovního materiálu vyhovujícím způsobem.

Svozy a rozvozy poštovního materiálu lze zajistit dvojím způsobem. Prvním způsobem je vytvoření „fiktivních služebních atrakčních obvodů“, jejichž náplní práce bude rozvoz poštovního materiálu pouze na ty pošty, z nichž vycházejí listovní doručovatelé. Snahou je zásobit tyto pošty peněžním přídělem a došlými listovními zásilkami co nejdřive, aby byl zachován počátek doručovací pochůzky od osmé hodiny ranní, jež je definován v základních kvalitativních podmínkách. Druhým možným způsobem je obsluha pošt v rámci doručovací pochůzky určených atrakčních obvodů. K tomuto lze využít stanovené motorizované doručovací obvody. 


\section{Závěr}

Snahou ČP je zajistit efektivní systém obsluhy na celém území České republiky. Jednou z možností jak lze toto zajistit je vytvoření pružné poštovní sítě, a tento předložený návrh je pouze jedním z několika variant. Ovšem návrh je možné provést pouze v případě, že Česká republika bude obsluhována $\mathrm{z}$ osmi sběrných přepravních uzlů, a že $\mathrm{z}$ depa Třinec budou vyjiždět na pochůzku pouze balíkoví doručovatelé. Samotný návrh centralizace počítá i s prrípadným úbytkem balíkových zásilek, kdy balíkové atrakční obvody budou nahrazovány motorizovanými atrakčními obvody.

\section{Literatura}

[1] ČERNÁ, A., ČERNÝ, J. Teorie řízení a rozhodování v dopravních systémech. Pardubice, 2004. 257 s. ISBN 80-86530-15-9.

[2] FOTR, J., DĚDINA, J. Manažerské rozhodování. Praha: Ekopress, 1997. 206 s. ISBN 80-901991-7-8.

[3] HRBÁČEK, P. et al. Poštovní přeprava, studijní text. 2006. $340 \mathrm{~s}$.

[4] VOLEK, J. Operační výzkum I. Pardubice: 2006. 111 s. ISBN 80-7194-410-6.

[5] MADLEŇÁK, R. Analýza vonkajšieho prostredia poštového podniku pre potreby optimalizácie premiestňovacieho procesu. 2004. In: Diagnostika podniku, controlling a logistika - S. 196-202

[6] MADLEŇÁKOVÁ, L.: Optimalizácia dodávacej služby zriad'ovaním dodávacích centier, In: Diagnostika podniku, controlling a logistika: V. medzinárodná vedecká konferencia : zborník prednášok a príspevkov : 21.-22. apríl 2010, Žilina. - Žilina : Žilinská univerzita, 2010. - ISBN 978-80-554-0175-1. - S. 211-219. 